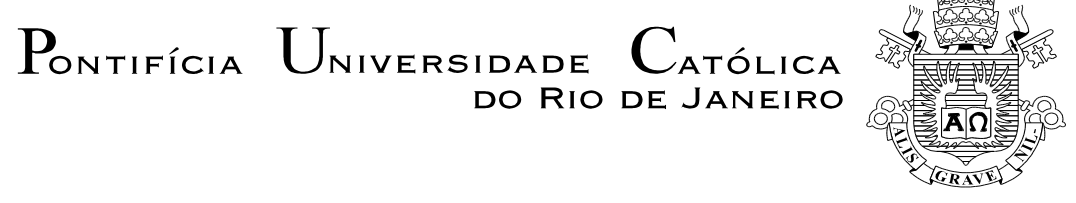

Mariana Newlands Silveira

Bibliomania no sistema literário

Dissertação apresentada como requisito parcial para obtenção do título de Mestre pelo Programa de PósGraduação em Letras da PUC-Rio.

Orientador: Heidrun Friedel Krieger Olinto de Oliveira

PUC-Rio, abril de 2006 


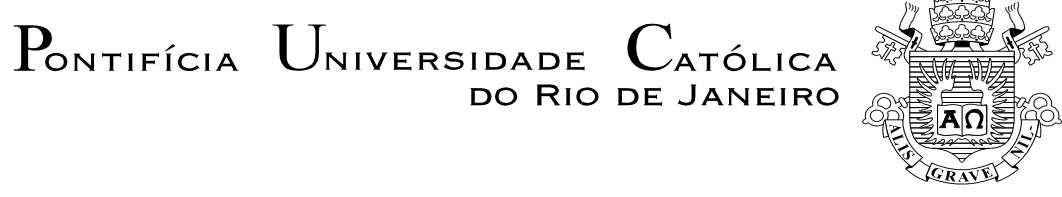

Mariana Newlands Silveira

\section{BIBLIOMANIA NO SISTEMA LITERÁRIO}

Dissertação apresentada como requisito parcial para obtenção do grau de Mestre pelo programa de Pós-Graduação em Letras do Departamento de Letras do Centro de Teologia e Ciências Humanas da PUC-Rio. Aprovada pela Comissão Examinadora abaixo assinada.

Profa. Heidrun Friedel Krieger Olinto de Oliveira Orientadora Departamento de Letras - PUC-Rio

Profa. Pina Maria Arnoldi Coco Departamento de Letras - PUC-Rio

Profa. Amélia Maria Cavalcante Lacombe Instituto de Letras - UFF

Prof. Paulo Fernando Carneiro de Andrade Coordenador Setorial do Centro de Teologia

e Ciências Humanas - PUC-Rio

Rio de Janeiro, de de 
Todos os direitos reservados. É proibida a reprodução total ou parcial do trabalho sem autorização da universidade, da autora e do orientador.

\section{Mariana Newlands Silveira}

Graduou-se em Desenho Industrial/ Comunicação Visual, pela PUC-Rio, em 1997, com projeto de pesquisa no campo da linguagem visual contemporânea. Estudou Graphic Design e Computer Graphics na Parsons School of Design, em Nova York. Atua como designer gráfica autônoma no mercado de design editorial e ilustração de livros.

Ficha Catalográfica

Silveira, Mariana Newlands

Bibliomania no sistema literário / Mariana Newlands Silveira ; orientador: Heidrun Friedel Krieger Olinto de Oliveira . - Rio de Janeiro : PUCRio, Departamento de Letras, 2006.

68 f. : il. ; $30 \mathrm{~cm}$

Dissertação (mestrado) - Pontifícia Universidade Católica do Rio de Janeiro, Departamento de Letras.

Inclui bibliografia

1. Letras - Teses. 2. Sistema literário. 3. História do livro. 4. Políticas do livro. I. Oliveira, Heidrun Friedel Krieger Olinto de. II. Pontifícia Universidade Católica do Rio de Janeiro. Departamento de Letras. III. Título. 
Agradeço à minha orientadora, Heidrun, pela incansável dedicação, carinho e amizade durante o processo de escrita deste trabalho, à CAPES, pela bolsa que me proporcionou estes anos maravilhosos de estudo, aprendizado e convivência no Departamento de Letras da PUC-Rio e a todos os que colaraboram para esta pesquisa com sua experiência e amor pelos livros. 


\section{Resumo}

Mariana Newlands Silveira. Bibliomania no sistema literário. PUC-Rio, 2006. 68p. Dissertação de Mestrado - Departamento de Letras, Pontifícia Universidade Católica do Rio de Janeiro.

A proposta deste trabalho é levantar uma série de questionamentos e curiosidades a respeito da relação homem-livro, primeiramente sob o ponto de vista das teorias contemporâneas da literatura - da década de 60 em diante partindo para uma análise sob o ponto de vista histórico - a importância do desenvolvimento da forma do livro, desde as primeiras tábuas de lei até a brochura encadernada que conhecemos hoje - e, em seguida, do ponto de vista estético e sensorial - aspectos da materialidade do papel, da tipografia, da forma, da capa, do peso, da diagramação. A análise destes fatores estabelece as bases para um aprofundamento acerca da evolução das interações do sistema literário no Brasil, da atuação de seus agentes e da interação entre eles, a sociedade e os demais sistemas. A pesquisa se propõe a compreender de que maneira o desenvolvimento material do objeto livro, ao longo dos séculos, propiciou e acompanhou também a evolução da relação do homem com este objeto, culminando com a produção literária pós-moderna, que se encaminha para fora dos limites do suporte do livro, mobilizando sentidos e explorando recursos gráficos e textuais que enriquecem e ampliam a experiência da leitura.

\section{Palavras-chave}

Sistema literário, história do livro, políticas do livro 


\section{Abstract}

Mariana Newlands Silveira. Bibliomania no sistema literário. PUC-Rio, 2006. 68p. Dissertação de Mestrado - Departamento de Letras, Pontifícia Universidade Católica do Rio de Janeiro.

My intention in this work is to raise a number of questions and to examine curious aspects of the relationship between man and book. The analysis of these points begins with the man-book relatioship from the perspective of the contemporary literary theories - from the 1960's on. Next comes the analysis of the historical perspective - the importance of the evolution and development of the shape of the book itself as an object, since the first stone and clay tablets to the hardback brochure we know today; and from the aesthetical and sensorial point of view - aspects of the material nature of the paper, of the typography, the shape, the cover, the weight, the graphic design and layout work. The analysis of these factors establish the basis to a thorough research about the evolution of the interactions of the literary system in Brazil, the role played by its agents and the interaction that occurs between their actions and those of the society and the remaining systems. This work intends to investigate in which ways the development of the physical aspects of the book throught the centuries has mirrored and paralleled the evolution of the relationship between man and book. The climax of such interaction can be sampled in the post modern literary production, whose borders have been extended beyond the limits of the physical object of the book, mobilizing man's senses and allowing the exploration of graphic e text resources that expand the experience of reading.

\section{Keywords}

Literary System, History of the book, Book politics 


\section{SUMÁRIO}

1. Introdução 9

1.1 Os sentidos do livro 9

2. Perspectivas teóricas 12

2.1 Modelos teóricos interativos 13

2.2 Perspectivas pragmáticas $\quad 22$

3. Transformações do livro e da leitura 31

3.1 Da tradição oral à escrita 31

3.2 Transformações da forma 33

4. O livro 38

4.1 O livro como objeto estético 38

4.2 A constituição material do objeto livro 40

5. Conclusão 52

$\begin{array}{ll}\text { Bibliografia } & 58\end{array}$

$\begin{array}{ll}\text { Anexos } & 60\end{array}$

ANEXO A. (p.44) Sumário de Primeiras Estórias, de Guimarães Rosa, por Luís Jardim $\quad 60$

ANEXO B. (p.48) Coleção Prosa do Mundo, editora Cosac \& Naify 61

ANEXO C. (p.51) Exemplares da Editora Finaflor: Nego tudo, de Andréa del Fuego, e A Defunta, de Rubens Miranda 62

ANEXO D. (p.54) Trilogia Griffin \& Sabine, de Nick Bantock 64

ANEXO E. (p.54) No longe dos Gerais, de Nelson Cruz 66

ANEXO F. (p.56) Noite do oráculo, de Paul Auster 67 
Dentre os instrumentos inventados pelo homem, o mais importante é, sem dúvida, o livro.

Os demais são extensões de seu corpo.

O microscópio e o telescópio são extensões da visão; o telefone, uma extensão da voz e, finalmente, temos o arado e a espada, ambos extensões do braço.

O livro, porém, é outra coisa.

O livro é uma extensão da memória e da imaginação.

Jorge Luís Borges, O Livro 